\title{
INCENTIVES TO PRIVATE U.S. INVESTMENT ABROAD UNDER THE FOREIGN ASSISTANCE PROGRAM
}

\author{
BRUQE E. GLUBB广 \\ VERNE W. VANGE, JR. +
}

\section{Introduction}

SINCE the inception of the United States foreign aid program with the Economic Cooperation Act of 1948, ${ }^{1}$ Congress repeatedly has exhorted the administrators of the program to utilize the authority given them to maximize the participation of private U.S. investment. This encouragement was evident, first, in the task of rebuilding the devastated economies of Western Europe, and, later, in the task of promoting the economic development of the less developed countries of the free world. ${ }^{2}$ In enacting the Foreign Assistance Act of 1961,3 Congress again expressed its strong preference for programs of assistance developed through private channels. Section 601 (b) (4) of the act requires that "wherever appropriate [the President shall] carry out programs of assistance through private channels . . . ." In addition, Congress gave the agency administering the foreign aid program-now called the Agency for International Development (AID) - a number of tools with which to promote private investment. Among the incentives available to private U.S. investors under the FAA of 1961 are loans, investment guaranties (i.e., insurance against losses arising from political and certain other events) and financial assistance in making surveys of investment opportunities.

The administrators repeatedly have responded with little more than lip service and the most limited stimulation of private U.S. investment resources." Several

$\div$ Member of the District of Columbia Bar. Formerly with the Office of the General Counsel, Development Loan Fund, and Agency for International Development.

+Member of the District of Columbia Bar. Attorney, Office of the General Counsel, Agency for International Development.

The views expressed herein are entirely those of the authors and not those of the Agency for International Development.

1. 62 Stat. 137 (1948).

2. See, e.g., Mutual Security Act of 1954, $\$ 413,68$ Stat. 846 (1954), as amended, 22 U.S.C. § 1933 (Supp. III, 1962).

3. 75 Stat. 424 (1961), 22 U.S.C. \$ 2151 (Supp. III, 1962). This bill provided for certain expansions of the foreign aid program and for reorganization of its administration. (Hereinafter cited occasionally as FAA.)

4. 75 Stat. 438 (1961), 22 U.S.C. \$ 2351 (Supp. III, 1962).

5. This resulted in extensive criticism during the hearings on H.R. 7372, H.R. 8400, and S. 1983, the bills which became the Foreign Assistance Act of 1961, 75 Stat. 424 (1961), 22 U.S.C. \$ 2151 (Supp. III, 1962). See, e.g., Hearings on H.R. 7372 [International Development and Security Act] and H.R. 8400 [Mutual Security Act of 1961] Bcforc the House Committee on Foreign Affairs, 87th Cong., 1st Sess. 323 (1961). (Hereinafter cited as 1961 House Hearings.) 
factors explain the reluctance of AID and the State Department to allow U.S. investors to enter an underdeveloped country. The first is a fear, often present in the Government, that the investor will conduct himself in such a way as to become unpopular with the local government or the people, thus overshadowing any economic gains which may be realized by his presence. In addition, it is sometimes noted that assistance channeled through private industry is not nearly so effective as government-to-government assistance in inducing a foreign government to commit itself to actions and programs regarded by the United States as critical to the successful use of its assistance. Finally, some investors have suggested that agency personnel prefer to deal with foreign governments rather than private investors, both because there is less likely to be congressional criticism of a loan on favorable terms to a foreign government than to a particular private investor, and because such a loan or grant increases the importance of agency personnel. This latter assertion proceeds on the theory that the standing of AID overseas personnel and U.S. ambassadors in the local diplomatic community may very well be determined by the amount of aid received by the host government. If a large portion of U.S. aid were channelled through private firms, AID personnel would tend to have less control and their importance would be diminished.

It may be that private investment is not appropriate in areas of short-term economic assistance, such as surplus food relief or budget support, or even in certain long-term programs involving basically public projects, such as roads and dams. But the values apparently placed upon private investment by the 1948 and 1961 acts do seem sound in the area of industrial development projects. First, private companies are in a better position to supply to less developed countries not only needed capital but also socially responsible managerial and entrepreneurial talent trained in modern business concepts. The United States Government, of political necessity, must rely entirely on local administration of capital and enterprise. Entrepreneurial talent which does exist in the less developed countries often is handicapped by outmoded business concepts and a lack of social responsibility which private American industry can supply. Finally, foreign aid channelled through private investors is less expensive to the U.S. economy because it is often more efficient than counterpart governmental operations and because private investment abroad can eventtally return a profit to the United States.

Generally, however, no real effort has been made to enlist the aid of private U.S. investment even in the limited area of industrial development. Morcover, private industry itself has hesitated to make investments in less developed countries for several economic reasons, ${ }^{6}$ including lack of a large market, trainted native manpower, or adequate transportation and power facilities. They also

6. Two surveys of businessmen have been conducted. The results of one, conducted by the U.S. Department of Commerce, have been published in Responses to Butsincss Qulestiomaire Regarding Private Investment Abroad (1959). The other was conducted by the National Industrial Conference Board, the results being published in Obstacles to Dirct Foreign Investment (1951). 
fear such political factors as import-export controls and government regulations having the cumulative effect of expropriation, as well as war, revolution, and other disruptions of business resulting from instability of the governments. Equally important, but less frequently mentioned, is the fear of the unknown. What does a Kansas City manufacturer know about doing business in Nigeria? $\mathrm{He}$ will be risking a substantial amount of capital, as well as time, effort and prestige, in a business and legal atmosphere that is almost completely unfamiliar. Even if that atmosphere is now favorable, it might suddenly change if he or the United States should fall out of favor with the local regime.

Many of the fears harbored by potential United States investors stem from a strong skepticism by the foreign governments themselves about the value of substantial private foreign investment. Many countries seem to regard such investment simply as a new form of colonialism, or a continuation of one of the worst manifestations of the old colonialism-exploitation of the natural and human resources of a less developed country by foreigners for their own profit. They fear that the net gain to the native economy will be small compared with the resulting drain on the nation's resources. Consequently, many less developed countries have enacted legislation which, although designed to meet understandable concerns, often discourages the foreign investor by its complexity and its tendency to limit his return or increase his risks. Even those nations which have passed legislation designed to encourage foreign investment often have enacted simultaneous legislation having a restrictive effect. Such legislation may take the form of exchange control, restricting repatriation of capital and earnings; restrictive tax legislation; employment restriction; restrictions on the importation of raw materials; or expropriation powers. In addition, foreign governments not adverse to private U.S. investment often strongly prefer AID assistance rendered directly to the foreign government, rather than assistance to private U.S. investors. This is due partly to the tendency of the officials and agencies of most governments to support projects which they themselves will administer. It is due also to an ideological bias of many governments toward the use of foreign aid resources for the public, rather than the private, sector of the economy, perhaps on a theory that a private industrial enterprise can always find financing more easily than can the government itself.

Thus, very little U.S. private investment has found its way into underdeveloped areas to date. ${ }^{7}$ In response, the recently enacted legislation is designed

7. Total direct foreign investment up to 1958 amounted to $\$ 27.1$ billion. See Wuitans, The United States Investarent Guaranty Prograar and Private Foreign Investarent 5 (1959). Of this, only $\$ 9.5$ billion was in Latin America, and just $\$ 4$ billion in Africa and Asia. Of the $\$ 4$ billion in Africa and Asia, nine-tenths has gone into the extractive industries such as petroleum and mining. See the discussion in The Mrutual Securitr Procrars, Fiscal Year 1961: A Stuararary Presentatyon 117-20 (1960); AItkeseld, Prosrotrig United States Prtvate Investurent Abroad 15 (1957).

Another indication of the small magnitude of U.S. investment abroad is that only $1.5 \%$ of the total assets of U.S. corporations are currently invested outside the U.S. and Canada, WhItaraN, op. cit. supra at 7 , and only $0.5 \%$ of all U.S. corporations have any forcign investment at all, MIKESELr, op. cit. stipra at 23. 
to induce U.S. businessmen to invest abroad by providing for increased profits and decreased risks. What follow are analyses of the specific inducements offered private investors under the FAA of 1961, an identification of the more important problems facing private investors using these inducements, and some suggestions as to how these inducements will, or should, be administered by AID to attain their apparent objectives.

\section{Development Loans}

The basic development tool of the Foreign Assistance Act of 1961 is the dollar-repayable development loan authorized by Title I of chapter $2{ }^{8}$ Under this title $\mathrm{AID}^{0}$ is authorized to make dollar repayable loans to promote the economic development of less developed friendly countries. ${ }^{10}$ Although such loans must emphasize assistance to long-range plans and programs, ${ }^{11}$ the basic statement of the purpose for which every development loan must be made- "to promote the economic development of less developed friendly countries and areas"-is very broadly worded. It appears to authorize loans made for the development of either economic resources or related social resources. ${ }^{12}$ Assistance for military, political and economic purposes concerned with stabilization

8. 75 Stat. 426 (1961), 22 U.S.C. $\$ 2161$ (1961). And see Pub. L. No. 565, 87th Cong., 2d Sess., \& 101 (Aug. 1, 1962). The fiscal year 1962 appropriation for this category of assistance was $\$ 1,112,500,000$, as compared with appropriations of $\$ 16,000,000$ for all other categories of economic assistance, including $\$ 275,000,000$ for the Contingency Fund, which is also available for Title I development loans. Foreign Assistance and Related Agencles Appropriation Act of 1962, 75 Stat. 717 (1961), 22 U.S.C. \$ 2151 (1961).

9. As agent of the President, to whom the authority is actually given.

10. Section 201 (b) of Title I, 75 Stat. 426 (1961), 22 U.S.C. $\$ 2161$ (1961), contains no limitations on the types of entities eligible for development loans, and $\S 635(\mathrm{~b}), 75$ Stat. 456 (1961), 22 U.S.C. $\$ 2395$ (1961), provides that such loans may be made to "suly intdividual, corporation, or other body of persons, friendly government or government agency, whether within or without the United States, and international organizations. . . " Hence, such loans are legally available to any organization or private enterprise, regardless of its place of organization or the nationality of its owners.

However, the requirement that such loans promote the economic development of "friend$1 y$ " countries would in practice eliminate organizations organized in countries not falling within this category. Such excluded countries would be those dominated or controlled by the international communist movement. See H.R. REp. No. 851, 87th Cong,, 1st Sess. 12 (1961). See also $\$ \$ 620$ (b) \& 620(f) of the Foreign Assistance Act of 1961, 75 Stat. 445 (1961), as amended, 22 U.S.C. $§ 2381$ (1961). Possibly also excluded pursuant to a much publicized amendment inserted by the FAA of 1962 would be those countries any governmental subdivision of which effectively expropriates property owned by a U.S. citizen or by any corporation, partnership or association not less than $50 \%$ beneficially owned by U.S. citizens and does not within six months of the expropriatory act "take appropriate steps" to discharge its obligations under international law to make equitable and speedy compensation for such expropriation. Foreign Assistance Act of 1961, § 620(e), 75 Stat. 439 (1961), as amended, 22 U.S.C. $\$ 2352$ (1961). However, it is arguable that a loan to a private borrower in such a country does not constitute "assistance to the government" of such country.

11. 75 Stat. 426 (1961), 22 U.S.C. \& 2161 (1961).

12. See Conf. Rep. No. 1088, 87th Cong., 1st Sess. 45 (1961). [Hereinafter cited as Conf. ReP.] 
rather than developmental growth of the economy, however, is covered by other sections of the act. ${ }^{13}$ Probably any loan for the construction of a new enterprise or the expansion of an existing enterprise which will serve to create new jobs, to increase economic productivity, or to supply goods or services which will feed into another sector of the economy and generate increased activity there, will satisfy this requirement.

In the making of development loans, the statute requires that the following factors be "taken into account": : $^{14}$

1. The availability of financing in whole or in part from other free-world sources on reasonable terms;

2. The economic and technical soundness of the activity to be financed;

3. The degree to which the activity gives reasonable promise of contributing to the development of economic resources or to the increase of productive capacities in furtherance of the purposes of economic development;

4. The consistency of the activity with, and its relationship to, other development activities being undertaken or planned, and its contribution to realizable long-range objectives;

5. The extent to which the recipient country is showing a responsiveness to the vital economic, political, and social concerns of its people, and demonstrating a clear determination to take effective self-help measures; and

6. The possible effects of successful development upon the United States economy, with special reference to areas of substantial labor surplus. ${ }^{15}$

Favorable conclusions on all six factors are not required as a matter of law to qualify a project for a loan. ${ }^{16}$ Section 201, however, does require considera-

13. 75 Stat. 435 (1961), 22 U.S.C. $\$ 2311$ (1961) (military); 75 Stat. 434 (1961), 22 U.S.C. $\$ 2241$ (1961) (political and economic stability).

14. 75 Stat. 426 (1961), 22 U.S.C. \$2161 (1961). The Foreign Assistance Act of 1962, which amended certain provisions of the 1961 Act, established a separate statutory title for development assistance to Latin America under the Alliance for Progress, including authorization of appropriation of $\$ 500$ million annually through fiscal year 1966 for dollar repayable development loans. Development loans made under the Alliance for Progress title are subject to nearly identical criteria as govern title I development loans. The only differences are that: (1) the third factor is omitted inasmuch as the special Latin Ameriean loans are to be directed to the development not only of economic resources, but also of human resources (schools, hospitals, etc) ; (2) the fifth criterion is modified by inclusion of a reference to the principles of the Act of Bogota and the Charter of Punta del Este; and (3) a new factor-the efforts made by recipient nations to repatriate capital in other countries by their own citizens-has been added. Except for these specific modifications, the discussion herein of development loans is applicable to development loans under the Alliance for Progress title. It should also be noted that nothing in the special Alliance for Progress title or elsewhere in the FAA includes or limits use of the Title I development loan funds, the investrment guaranty authorities, etc., for Latir American projects.

15. The factors numbered (1), (2), (3), and (6) are quite similar to the criteria specified for loans by the Development Loan Fund-a predecessor agency of AID in the field of development lending-under $\$ 202$ (b) of the Mfutual Security Act of 1954, 6S Stat. 846 (1954), as amended, 22 U.S.C. $\$ 1872$ (b) (1961). The factors numbered (4) and (5) are derived from general legislative injunctions to the DLF contained in $\S 202$ (b).

16. This is made clear by comparison with $\S 211$ of the FAA, 75 Stat. 427 (1961), 22 U.S.C. $\$ 2171$ (1961), relating to the criteria for furnishing development grants and tech- 
tion of all six factors, and, accordingly, a loan applicant must keep them in mind when considering and preparing an application for a development loan.

The first three criteria are reasonably self-explanatory. The fourth criterion reflects a desire to use development loans to support well-conceived plans drawn up by the recipient countries for their economic development. Under this criterion, private investors should endeavor to have their projects included in foreign governmental plans, in order to establish a relationship to the recipient country's development program. ${ }^{17}$ Endorsement of the priority of the project by the host government and the United States team will be, as in the case of Development Loan Fund applications, of critical importance. ${ }^{18}$

The fifth criterion-the "self-help" criterion-is the one emphasized most strongly in the congressional presentation. ${ }^{10}$ Inasmuch as the criterion relates to self-help measures by the recipient country rather than by the private applicant, there is little the private applicant can do to place his application in a good posture with regard to this criterion except to inform himself on the status of such self-help measures in the recipient country as tax reform, land reform, educational development, and economic development planning. ${ }^{20}$ An initial check with AID is probably the easiest way to determine whether any problem exists with regard to this criterion in the particular country involved.

nical assistance. That section provides six criteria which the President "shall take into account," including "the possible adverse effects upon the United States cconomy, with special reference to areas of substantial labor surplus." 75 Stat. 427 (1961), 22 U.S.C. § 2171 (1961). It then states that:

If the President finds that assistance proposed to be furnished under . . . [the Development Grant] title would have a substantially adverse effect upon the United States economy, or a substantial segment thereof, the assistance shall not be furnished.

No such prohibition appears with regard to any of the development loan criteria in $\$ 201$. The version of the bill originally passed by the House included the prohibition of $\S 211$ in $\S 201$ as well, but this was stricken from $\S 201$ in conference. ConF. REp. at 46 .

17. In addressing himself to the relationship between country development plans and private enterprise, the Hon. Frank M. Coffin, Chairman, Program Development Group of the President's Task Force on Foreign Economic Assistance, and presently Depuly Aclministrator of AID, told the House Committee on Foreign Affairs that :

[W] would not consider that a sensible national program was one which did not leave adequate scope for the private sector because we feel that the resources that can be attracted by private domestic and foreign investment are an important part of any country's sensible approach to its future.

1961 House Hearings at 886.

18. See 1961 House Hearings at 880.

19. See, e.g., 1961 House Hearings at 823; Hcarings on S. 1983 Bcforc the ScHalc Committee on Foreign Relations, 87th Cong., 1st Sess. 205 (1961). [Hercinafter cited as 1961 Senate Hearings.]

20. It should be noted that as a matter of language, "a clear determination to takc effective self-help measures" refers to a present state of mind regarding future actions rather than to past action or present action. However, the criterion of a "clear deterministion" must mean a credible determination-one that is backed up by a showing of meaningful and realistic plans for the future which, with the passage of time, must be translated into action. As time passes, the criterion will-and should-become increasingly difficult to satisfy. 
The sixth criterion is addressed to both good and bad effects on the U.S. economy. Thus, such factors as the creation of foreign industries which will compete with U.S. industry in both foreign and U.S. markets and the possibility of adverse effects upon the U.S. balance of payments position are considered, as well as benefits to U.S. business from requirements that loan funds be used for procurement of U.S. goods and services.

In administering the development loan program, AID has extended the dollar-repayable development loans to government borrowers on extremely "soft" terms, usually an interest rate of three quarters of one per cent and a repayment period of forty years with a grace period on principal repayment of ten years, in accordance with the Administration's 1961 legislative presentation. ${ }^{21}$ Private borrowers have not been accorded terms as favorable as this, however. The feeling was expressed in the Administration's 1961 presentation to Congress that according such extremely liberal terms to some private borrowers would give them an extremely unrealistic debt structure which might give them an unfair advantage over their commercial competitors. ${ }^{22}$ The host countries would probably be unwilling to make dollars available for private borrowers to repay loans on terms similar to those accorded by the Development Loan Fund ${ }^{23}$ for loans repayable in local currency-five and three quarters per cent interest and, for example, fifteen years. Accordingly, the thought was expressed in the report of the House Committee on Foreign Affairs on the House version of the bill that repayment of a private loan in dollars might be arranged by allowing a private borrower to repay the loan on DLF-type terms in local currency to an account which the recipient country would agree to convert into dollars over the longer period of time normally allowed for loans by AID to the government itself. ${ }^{24}$ This is in fact the arrangement which AID has used in almost all its loans to private borrowers.

Sections 604 (a) ${ }^{25}$ and 620 (d), ${ }^{26}$ although outside Title I, are particularly applicable to such loans and should be borne in mind by private applicants.

21. See H.R. REp. No. 851, 87th Cong., 1st Sess. 14 (1961); S. Rep. No. 612, 87th Cong., 1st Sess. 8 (1961).

22. 1961 House Hearings at 646-47; 1961 Scuate Hearings at 210.

23. See note 15 supra.

24. H.R. REP. No. 851, 87th Cong., 1st Sess. 14-15 (1961). MIaking the loan in this fashion would appear to present at least two conceptual problems: whether a true dollarrepayable loan within the meaning of the statute has been established; and whether use by the government of local currency received from the private borrower until the later conversion into dollars would be in effect a loan of the local currency to the government, which loan may be of questionable legality. These problems should not be regarded too scriously, however. There can be little doubt that AID could legally make the loan to the government, to be repayable on the extremely soft terms with provision for relending of the funds to the private company with repayment in local currency on DLF-type terms. In substance this arrangement is no different from that where the loan is made directly to the private borrower, and both arrangements should therefore be regarded as within the authority of Title I.

25. 75 Stat. 439 (1961), 22 U.S.C. § 2354 (Supp. III, 1962).

26. 75 Stat. 444 (1961), 22 U.S.C. $\$ 2370$ (Supp. III, 1962). 
Section 604(a) limits procurement with foreign aid funds to the United States unless the President determines that offshore procurement will not result in adverse effects to the U.S. economy outweighing the advantages of such procurement. In formal actions, ${ }^{27}$ President Kennedy determined that offshore procurement of items for non-military programs from free-world sources would not result in such adverse effects, except that procurement from the following countries was to be permitted only where authorized in specific cases by the Secretary of State: Australia, Austria, Belgium, Canada, Denmark, France, Germany, Italy, Japan, Luxembourg, Monaco, The Netherlands, New Zealand, Norway, The Union of South Africa, Spain, Sweden, Switzerland and United Kingdom. Thus far, AID development loan policy has been even more restrictive than that established as a minimum by the President's determination, in that procurement has generally been limited to the United States.

Section 620 (d) prohibits the making of Title I development loans for the construction or operation of any "productive enterprise" in any country if it will compete in the United States with U.S. enterprise. The prohibition applies only "to situations where the product of the enterprise being assisted will compete in the U.S. market directly with the product of the United States."2s The host country may, however, avoid the effect of this prohibition by agreeing to establish procedures to prevent exportation to the U.S. of more than 20 per cent of the annual production of the assisted enterprise during "the life of the loan."

It is difficult to say just what level of lending to private enterprise-both U.S. and foreign owned-can be expected from the development loan funds. Past experience indicates, however, that approximately $20-25$ per cent of the loans will go to private borrowers, including privately owned intermediate financing institutions such as development banks, and that these investors will utilize approximately 10-15 per cent of total loan funds. ${ }^{20}$ Althoutgh the Administration's presentation to Congress did not highlight loans to private borrowers, the "Javits amendment" to section $601^{30}$ is a strong indication of congressional desire for extensive use of the development loan funds for loans to private borrowers. This amendment was proposed and adopted after the bill was reported out of committee and is an addition to the provision in section 102(f) encouraging free enterprise and private participation, which is derived from section 413 of the Mutual Security Act of 1954.31 The "Javits amendment" provides that the President, to whom the FAA of 1961 delegates the development loan function, shall

... wherever appropriate carry out programs of assistance through private channels and to the extent practicable in conjunction with local

27. 26 Fed. Reg. 10543 (1961) ; 27 Fed. Reg. 7603 (1962).

28. Conf. REP. at 62 (1961).

29. This calculation is based on information supplied by AID's Office of Development Financing and Private Enterprise.

30. So named for its proponent, Senator Jacob Javits, this section could also be characterized as the "private enterprise section" of the FAA of 1961.

31. 68 Stat. 846 (1954), as amended, 22 U.S.C. \& 1933 (Supp. III, 1962). 
private or governmental participation, including loans under the authority of section 2161 of this title to any individual, corporation, or other body of persons. ${ }^{32}$

\section{Cooley Loans}

The transfer of administration of the so-called Cooley loan program ${ }^{33}$ from the Export-Import Bank of Washington to AID was effected pursuant to the FAA of 1961.34 Under the Cooley loan program, not more than 25 per cent ${ }^{35}$ of the currencies received from the sale of surplus agricultural commodities is available for loans to United States firms or their affiliates for business development and trade expansion in the nations purchasing such commodities, and for loans to United States or foreign firms for the establishment of facilities for aiding the utilization, distribution, or consumption of United States agricultural products. Each loan must be approved by the host government, and no loan may be made for the manufacture of any products to be exported to the United States in competition with products produced in the United States or for the manufacture or production of any commodity to be marketed in competition with United States agricultural commodities or the products thereof. AID has interpreted this latter requirement as meaning only substantial competition. As in any standard employing the adjective "substantial," the crucial dividing line cannot be stated precisely as a general rule but is leit to decision in specific cases. Repayment terms for Cooley loans are related to the purpose of the financing and usually range between five and ten years. Interest rates are set by agreement with the host country government and are approximately equivalent to local development bank rates. These range from $6-8$ per cent. Ioans are repayable in the currency borrowed.

The initial problem for a potential applicant is to determine whether he falls within the category of those eligible for a loan. Inasmuch as nothing in the legislative history of section 704 of the Foreign Assistance Act indicates any congressional desire to change the administrative policies or practices relating to the Cooley program, AID has tended to follow these in many respects, including eligibility standards. ${ }^{36}$ Under the Export-Import Bank ${ }^{37}$ standards, a

32. Section 601 (b) (4), 75 Stat. 438 (1961), as amended, 22 U.S.C. \$ 2351 (Supp. III, 1962).

33. The so-called Cooley loan program is named after Representative Harold Cooley, author of the program. Such loans are authorized by $\S 104(\mathrm{e})$ of the Agricultural Trade Development and Assistance Act of 1954, 68 Stat. 456 (1954), as amended, 71 Stat. 345 (1957), 7 U.S.C. $\$ 1704$ (e) (1958). The entire act is more familiarly lnown as "P.L. 480."

34. FAA of 1961, § 704, 75 Stat. 463 (1961), 7 U.S.C. § 1704 (Supp. III, 1962), authorizes the transfer of the Cooley loan program to "such agency as the President shall direct" The actual transfer was accomplished by Exec. Order No. 10900, 26 Fed. Reg. 143 (1961), as amended by Exec. Order No. 10972, 26 Fed. Reg. 10469 (1961); Degartment of State Delegation of Authority No. 104, 26 Fed. Reg. 10608 (1961).

35. Although the statutory language specified that the $25 \%$ figure is a maximum, the legislative history of the provision clearly indicates a congressional intention that the Cooley loan program utilize as much of the $25 \%$ as possible. See CoNr. REP. at 4.

36. The following discussion of policies and practices relating to Cooley loans is based on discussions with Eximbank and AID officials.

37. Hereinafter referred to as Eximbank. 
U.S. "firm" is any individual who does business in the U.S., regardless of citizenship, or any corporation, partnership, or association organized under the laws of the United States or any of its states or territories. Although Eximbank would not have regarded substantial ownership of such a corporation by nonU.S. citizens as rendering the corporation ineligible, AID has apparently not yet determined whether to follow this position. AID has indicated, quite properly, that it would not regard as eligible a U.S. corporation organized by nonU.S. citizens for the sole purpose of obtaining a Cooley loan.

The overall test regarding eligibility appears to have been whether the enterprise to be financed by the loan has a substantial U.S. flavor in terms of its general proprietary and commercial interest, and the participation of capital and skills of U.S. citizens. For the case of an affiliate, the Eximbank had no strict rules, but decided each case on the basis of a number of factors, including the degree of ownership or control by a U.S. firm, common ownership of a U.S. firm and the applicant by a third firm, and the general commercial and operating ties between the U.S. firm and the applicant. The general rule of thumb followed by both Eximbank and AID has been to require at least a 20 per cent equity interest by a U.S. firm in an affiliate applicant. ${ }^{\text {as }}$ The applicant also qualifies if the 20 per cent equity is held by a wholly owned foreign subsidiary of a U.S. firm.

In addition to the general interest of an American firm in a U.S. affilinte applicant for a Cooley loan, AID has tended to require that the U.S. firm make a substantial commitment to the particular project being financed. This commitment has usually taken the form of a guaranty of repayment by the U.S. firm, a commitment to retain the equity interest in the applicant on the basis of which the loan was made, or an agreement by the U.S. firm to manage the project throughout the life of the loan. An interesting innovation in Coolcy loan administration by AID has been to offer, as part of any repayment guarantee from a U.S. firm affiliated with a Cooley borrower, a clause releasing the guarantor from all or part of his obligations where the borrower's business has been totally or partially impaired by expropriation or war dannage. Such a clause, for which AID exacts no fee, obviates any necessity that a U.S. gutrantor might otherwise feel to purchase specific risk investment guarmities ${ }^{30}$ against such losses.

Cooley loans are available to finance the purchase of goods and services of host country origin, to provide working capital, and, in exceptional cases, to refinance short-term indebtedness. Cooley loans have financed such projects as the construction of a fiberboard plant in Greece; working capital and costs of fixed assets for construction of a Turkish plant to manufacture rubber tires and tread rubber; and costs, including working capital, of the expansion of the sales and service operations of a sewing machine company in Pakistan. The

38. Hearings on S. 2996 Before the Senate Committce on Forcign Relations, 87th Cong., 2d Sess. 53 (1962). [Hereinafter cited as 1962 Scnatc Hearings.]

39. See text accompanying note 6 supra for a discussion of these AID guaranties; see also text at notes $51-81$ infra. 
availability of Cooley loan funds-and the consequent ease of obtaining a Cooley loan-varies widely from country to country. For example, sufficient Cooley funds are available in India, where a large P.I. 480 program has been in effect for several years, while few Cooley funds are available where the P.L. 480 program has been relatively smaller and the demand for Cooley funds by U.S. investors has been large.

In more than four years of activity, ending September 30, 1962, the Eximbank and AID have authorized 18S Cooley loans in the currencies of nineteen countries. ${ }^{40}$ Loans have ranged from several million dollars to less than $\$ 100$,000 in foreign currency equivalent. The loan total is the equivalent of $\$ 109.8$ million. The available balance of Cooley funds not yet obligated was the equivalent of $\$ 124,372,828.97$ on September 30, 1962.

\section{Investment Surveys}

The one new tool for stimulating private U.S. investment in the less developed countries is the authority to participate in the financing of surveys by potential private investors of investment opportunities in the less developed countries and areas. ${ }^{41}$ Under the Technical Cooperation Program of the International Cooperation Administration (ICA) - the predecessor agency of AID in the Technical Cooperation field-financing was available for studies of the feasibility of possible investments to be undertaken or managed by U.S. companies. ${ }^{42}$ ICA policy, however, allowed such financing only to private organizations that would not benefit directly from the study. In addition, public bidding was required on feasibility study contracts with few exceptions. Accordingly, there was thought to be no way to respond positively to the initiative of a private company that would have liked to explore the feasibility of a possible investment abroad but did not feel itself justified in spending money for the needed study. ${ }^{43}$ The FAA of 1961 gives specific authority for the President to assist in financing such surveys undertaken by any U.S. citizen, or any corporation, partnership or other association substantially beneficially owned by U.S. citizens. ${ }^{44}$ The statute does not require that the U.S. charge a fee for its participation in the financing of an investment survey, and AID has indicated that none will be charged.45

Although the language of the investment survey provision itself does not state that preference in the financing of investment surveys will be given to operating companies, as opposed to professional survey companies, the language of section 231(b) carries a clear implication that the authority was created

40. Cooley loan funds are available or will be available shortly in Ceylon, Republic of China, Ecuador, Finland, Greece, Iceland, India, Indonesia, Iran, Israel, Palistan, Paraguay, Philippines, Sudan, Syria, Tunisia, Turkey, United Arab Republic, and Victnam.

41. 75 Stat. 432 (1961), 22 U.S.C. \$\$ 2191-93 (Supp. III, 1962).

42. Mutual Security Act of $1954, \S 307,68$ Stat. 842 (1954).

43. See H.R. REP. No. 851, 87th Cong,, 1st Sess. 38-40 (1961); S. REP. No. 612, 87th Cong., 1st Sess. 17-18 (1961).

44. On interpretation of this statutory phrase, see text accompanying notes 64-68 infro.

45. AID Policy Guideline No. 1, p. 3 (1961). 
primarily to provide assistance to potential investors rather than professional survey companies. Section 231 (b) provides that:

In the event that a person who has undertaken a survey in accordance with . . . this title determines, within a period of time to be determined by the President, not to undertake, directly or indirectly, the investment opportunity surveyed, such person shall turn over to the President a professionally acceptable technical report with respect to all matters explored. Such report shall become the property of the United States Government, and the United States Government shall be entitled to have access to, and obtain copies of, all underlying correspondence, memorandums [sic.], working papers, documents, and other materials in connection with the survey. ${ }^{46}$

The implication is supported by the legislative history. In the House Report, for example, the statement is made that

... preference will be given, where possible, to contractors who indicate a positive interest in undertaking the investment to be studied. Such con* tractors may, however, employ as subcontractors, professional organizations in a manner consistent with their usual practice. ${ }^{47}$

The provision quoted above is replete with problems to be resolved in negotiations between lawyers for the Government and the private company. Although the statute requires only that the report be turned over to the United States if the surveyor makes a positive determination not to make the investment within a certain period of time, it appears likely that Congress did not intend to allow the surveyor to keep the report if he made no decision at all during the established time period. Probably the drafting of the provision is faulty and the intention was to regard the surveyor's failure to make a positive decision to invest within the prescribed time limit as a determination not to make the investment.

Questions are then presented as to what constitutes a positive or negative decision to make the investment. It would seem that for a surveyor to retain the rights to his survey, the statute requires an unequivocal decision by the investing company to proceed with the investment within a specified time regarded by AID as reasonable. Thus, in a survey of paint manufacturing in Pakistan by a U.S. company, AID required the surveyor to "take action to invest in such investment opportunity" within a specified period of time. If the surveyor takes such action to invest, he must repay to AID all funds disbursed by it for the survey, and if he does not take such action, he must turn over the technical report on the survey. If he changes his mind and makes the investment within two years after his delivery of the report, he must repay the AID funds. ${ }^{48}$

46. Foreign Assistance Act of 1961, § 231 (b), 75 Stat. 432 (1961), 22 U.S.C. $§ 2191$ (b) (Supp. III, 1962).

47. H.R. REP. No. 851, 87th Cong., 1st Sess. 39 (1961).

48. See Hearings on Foreign Operations Appropriations for 1963 Before a Subcommittee of the Committee on Appropriations, 87th Cong., 2d Sess., pt. III, at 895 (1962). 
Other difficult problems will arise in connection with determining the extent of financial participation in an investment survey allowed of the United States. Section 231 (a) limits such participation to " 50 per centum of the total cost of any such survey." The possibility that the investment survey authority would be used to pay for the half of the expenses of trips of corporate executives which income tax deductions do not finance troubled at least one congressman. ${ }^{49}$ Hence, AID will probably be quite careful in determining allowable costs for each survey. Problems will undoubtedly develop in determining such things as reasonable portion of general overhead to be allocated to the survey and expenses for survey personnel.

Another problem to be resolved relates to the scope of a survey which may be financed. Such a survey would certainly include a study of market conditions and pertinent government regulations. A more difficult question is the extent to which the study might include feasibility studies of the technical adequacy of a plant design or production process to be used. It appears that the statute was probably intended to cover not technical matters peculiar to the nature of a particular enterprise, but matters related to the feasibility of profitably operating such an enterprise in a particular country. Of course, the latter will often include factors related to technical feasibility, such as the possibility of using substitutes where conventionally used raw materials are not readily available.

Surveys of extraction opportunities are not eligible for financing under title IV. This excludes surveys directed to ascertaining the existence, location, extent, or quality of any deposit of ore, oil, gas, or other mineral, and to determining the feasibility of undertaking operations for the mining or other extraction of any such materials or for the processing of any such material to the stage of commercial marketability. ${ }^{50}$

For the fiscal year ended June 30, 1962, Congress appropriated $\$ 1,500,000$ for the investment survey program. Inasmuch as the program was new to both AID and the business public, AID was able to make final only one investment survey during fiscal year 1962 - the $\$ 3,500$ survey (of which AID is to pay one half) of paint manufacturing in Pakistan mentioned earlier. Although AID, in anticipation of a greatly stepped-up program in fiscal year 1963, had requested a $\$ 2,000,000$ appropriation for that period, Congress, in view of the fiscal year 1962 record, simply reapportioned the balance of the $\$ 1,500,000$ appropriated for fiscal year 1962 (i.e., $\$ 1,500,000$ less the $\$ 1750$ obligated by AID in fiscal year 1962 for the Pakistan paint survey).

\section{Investment Guaranties}

Investment guaranties-familiar development tools made more widely available by the 1961 Act-are basically insurance contracts under which the United

49. See statement by Representative Otto E. Passman (D. La.), Chairman of the powerful Subcommittee on Foreign Operations of the House Committee on Appropriations, Hearings an Foreign Operations Appropriations for 1962 Before the Subcommiltee of the House Conmittee on Appropriations, 87th Cong., 1st Sess. 318-19 (1961).

50. Foreign Assistance Act of 1961, § 233(b), 75 Stat. 432 (1961), 22 U.S.C. § 2193 (b) (Supp. III, 1962). 
States agrees to insure private investors against losses arising from certain political and, in some cases, business risks. This is potentially one of the most effective tools for promoting private investment in underdeveloped countries, but the failure of the foreign aid agencies to administer the program aggressively has prevented it from realizing its potential.

The use of investment guaranties as a foreign aid tool was originally proposed by a committee of the American Bar Association." The ABA committee justified the proposal on the ground that stimulation of the flow of private capital would be less expensive for the U.S. Government than direct government-to-government loans. In addition, the committee noted that, if a sufficient amount of private capital could be encouraged to move abrond, direct U.S. Government assistance could be more quickly ended.62 As a result of the ABA's efforts Congress granted ${ }^{63}$ authority to issue guaranties against the risk of inconvertibility of currency. ${ }^{54}$ This authority was rarely used, ${ }^{56}$ and so Congress still intent upon enlisting the aid of private capital, authorized the issuance of

51. See Hearings on United States Assistance to European Economic Recovery Bcfore the Senate Committee on Foreign Relations, 80th Cong., 2d Sess., pt. III, at 1080-1101 (1948); Hearings on United States Foreign Policy for a Post-War Recovery Program Before the House Committee on Foreign Affairs, 80th Cong., 1st \& 2d Sess., pt. I, at 835-71 (1948); Hearings on H.R. 2362 Before the House Committee an Forcign Affairs, 81st Cong., 1st Sess., pt. II, at 631-70 (1949); Hearings on S. 2197 Before the Scnatc Committee on Banking and Currency, 81st Cong., 1st Sess. 75-111 (1949).

52. See, e.g., Hearings on United States Foreign Policy for a Post-War Recovery Program Before the House Committee on Foreign Affairs, 80 th Cong., 1 st \& $2 \mathrm{~d}$ Sess., pt. I, at 870 (1948).

53. Economic Cooperation Act of 1948, \& 111 (b) (3), 62 Stat. 144-45 (1948).

54. The ABA's proposal called for much broader guaranty authority than the inconvertibility authority granted by Congress. In addition, an integral part of the program proposed by the $A B A$ was the acceptance of a number of obligations by the host country, including membership in the International Trade Organization. The object of the proposal was not only to encourage the movement of U.S. capital to Europe, but also to encourage the rule of law in international financial transactions.

55. The report of the House Foreign Affairs Committee on the $\mathbf{1 9 4 9}$ foreign aid bill expressed its disappointment in these words:

These figures fall far short of the expectations of the Congress in originally legislating the convertibility guaranty provision.

H.R. REP. No. 323, 81st Cong., 1st Sess. 20 (1949). The Committee went on to suggest that broader coverage was needed and proposed that coverage also be granted for risks of ... seizure, confiscation, or expropriation; destruction by riot, revolution, or war ; any law, ordinance, regulation, decree, or administrative action (other than measures affecting the conversion of currency), which in the opinion of the Administrator prevents the further transaction of the business for which the guaranty was issued,

H.R. REP. No. 323, supra at 21. The Senate refused to go along with this expansion, stating: The committee felt that ... broadening the terms of the guaranties would not result in substantial amounts of increased investments unless the guaranty was made so broad that, in fact, this Government would assume most of the risks which private capital should be expected to carry.

S. Rep. No. 100, 81st Cong., 1st Sess. 9 (1949). 
expropriation insurance in $1950^{56}$ and war risk insurance in 1956, 51 while requesting in no uncertain terms that the agency go forth and use them. ${ }^{\text {ss }}$ The program still faltered, however, and in 1957 a new agency, the Development Loan Fund (DLF), was authorized to issue guaranties against any type of loss, except that it could not insure equity investments against normal business risk. ${ }^{59}$ This authority was the broadest ever given a foreign aid agency, but a number of problems, both real and imagined, plus lack of administrative interest, prevented any significant use of it..$^{60}$

56. Foreign Economic Assistance Act of 1950, § 103(d), 64 Stat. 199 (1950), inserted the following language in the guaranty statute:

It being the intent of the Congress that the guaranty herein authorized should bc used to the maximum practicable extent and so administered as to increase the participation of private enterprise in achieving the purposes of this Act, the Administrator is authorized to issue guaranties up to a total of $\$ 200,000,000$.

57. Miutual Security Act of 1956, \& 8(k)(3), 70 Stat. 558 (1956).

58. In 1952 the House Foreign Affairs Committee registered its disappointment in these words:

One of the basic principles which the Congress has emphasized in the statutes governing the Mutual Security Program is the importance of private-capital investment as a potent force in raising the economic and social standards of underdeveloped areas. Not only does private investment bring capital, but it also brings with it technical knowledge and management experience, so sorely needed. Further, it relieves the American taxpayer, in the long run, of the burden of governmental forcign aid where cooperative aid can be appropriately handled by private sources. MIoreover, private capital offers a natural vehicle for close cooperation between private citizen and private citizen rather than between government and government, and hence is of special importance. There are several provisions in the law which deal with this principle .... They were seriously and carefully written by the legislative branch. It was, and is, intended that they be implemented. The committee is not satisfied that the Director for Mutual Security has exerted all the reasonable effort possible to implement those provisions. ... The point is that private capital has a definite place in the program which should be recognized by the executive branch and our partners in mutual security.

H.R. REP. No. 1922, 82d Cong., 2d Sess. 62 (1952).

Two years later the House Committee again voiced its criticism of the administration of the program:

[T] he fact remains that practically nothing has been accomplished in 2 years. Accordingly, the committee feels it necessary to again emphasize that it is the intention of Congress, expressed in that provision of the guaranty legislation carried over in the present bill ... that the guaranty program-"shall be used to the maximum practicable extent and shall be administered under broad criteria so as to facilitate and increase the participation of private enterprise in achieving any of the purposes of this Act."

H.R. Rep. No. 1925, 83d Cong., 2d Sess., pt. 1, at 88 (1954). See also H.R. REP. No. 1802, 81st Cong., 2d Sess. 42 (1950); H.R. Rep. No. 569, 83d Cong., 1st Sess. 58 (1955).

59. Mutual Security Act of $1957, \S 202$ (b), 71 Stat. 357-58 (1957).

60. While the ICA and DLF authorities were designed to be complementary, they were in fact competitive because they both operated in the same area, but onc was broader than the other. Not only was DLF's coverage authority broader, but also DLF was not required to obtain a bilateral agreement with the host country before issuing guaranties, as was ICA. DLF did not feel that it could issue guaranties in a country with which ICA was negotiating a bilateral agreement because to do so would have undercut the ICA negotia- 
Accordingly, it must be recognized that the investment guaranty program so far has achieved only the most limited success. ${ }^{61}$ The responsibility for this disappointing performance of the program can be laid partly on Congress, which has been very slow to enlarge the coverage to a realistic level, and partly on the administrators of the aid program, who have usually been more intent upon protecting the U.S. Treasury than on using private enterprise as a foreign aid tool. In defense of both Congress and the administrators, however, it must be noted that it has never been very clear how much or what kind of encouragement an investor must have to make him invest in an underdeveloped country. Congress when legislating, and the administrators when negotiating guaranty contracts, appear to have asked themselves, "How little can we give the investor and still get his help?" If one assumes that many projects could be built either with public funds or with Government guaranteed private funds, this has clearly been a penny wise and pound foolish approach, since it is demonstrable that private funds, even with the broadest possible Government gtar * anty, are less expensive from the U.S. Government standpoint than are public funds. ${ }^{62}$

The investment guaranty authority contained in the Foreign Assistance Act of 1961 reflects the reluctance of Congress to give the investor anything more than is absolutely necessary, ${ }^{63}$ and the actions of AID thus far reflect the

tions. Similarly, DLF could not issue a broader guaranty than ICA was authorized to issue without encouraging all investors to seek DLF, rather than ICA, guaranties. One might expect that in such a competitive situation the agency with the broader authority would issue all the guaranties. It is characteristic of the administration of the guaranty program, however, that this was not the case.

61 . Only three guaranties aggregating $\$ 57.9$ million were issued by DLF, and only onc of these covered an equity investment. The ICA authority, because of legislative and administrative limitations, has issued only $\$ 913$ million in guaranty contracts in the more than thirteen years since the inception of the program. Allowing for double (and triple) counting, since the value of a single investment is counted for each risk covered, this means that only approximately $\$ 600$ million in new investment has been covered by guaranties. In the time it took to issue this amount of guaranties, nearly $\$ 50$ billion of economic loans and grants were made, and more than $\$ 80$ billion of all types of aid were issued. Clearly, the Investment Guaranty Program has so far been merely a footnote, and a minor one at that, to the foreign aid program.

62. Assume, for example, that the U.S. borrows money at $4 \frac{\pi}{2} \%$ which it relends for foreign aid at the rate of $3 / 4 \%$ (the apparent return to AID on its loans). The net loss to the U.S., if all loans are repaid, is $33 / 4 \%$. In the case of loans, the U.S. takes not only all the political risks covered by guaranties, but the business risk as well, because if the borrowing entity fails, the loan is not repaid. In the case of loans, then, it can be stated that the U.S. takes all risks incident to repayment for a net loss of $33 \%$ \%. In the case of guar. anties, on the other hand, the U.S. is not deprived of the use of any funds, but reccives a fee of from $\mathrm{I} / 2 \%$ to $2 \%$ depending upon the risks assumed. Moreover, in no case is the risk assumed under a guaranty as large as the risk assumed under a loan:

63. The Administration proposed an "all risk" guaranty authority to replace the former broad DLF authority. Administration witnesses indicated, however, that in the normal case less than $100 \%$ of the investment would be insured. Congress responded by limiting all risk guaranties to $75 \%$ of any investment. The Administration indicated that it woutd not normally insure against fraud or misconduct for which the investor was responsible 
same cautious approach used in the past. Despite these limitations, however, the present investment guaranty program offers significant benefits to private investors and, if private investors are sufficiently ingenious, it can be a very effective tool.

A threshold question for a lawyer in securing any type of AID financing is whether his client is eligible. To qualify for an investment guaranty an applicant must be a United States citizen or a corporation, partnership, or other association created under the laws of the United States or of any state or territory "and substantially beneficially owned by United States citizens," or a wholly-owned foreign subsidiary of any such corporation. ${ }^{\text {ot }}$ The basic problem with this language is what constitutes "substantial beneficial ownership."

In considering this, one must at least take into account the two apparent policy bases of the eligibility requirement : the desire to bring U.S. supervised or operated enterprise into the less developed countries to provide the benefit of U.S. technical and managerial know-how, and the desire to ensure that a majority of the profits from foreign investment assisted by the investment guaranty and investment survey programs go to the U.S. taxpayers, who pay for such programs. The latter points toward a requirement of at least majority U.S. stock ownership. Although such majority stock ownership is not necessarily a guaranty of control in every case, control would follow in the normal case and it appears likely that AID will adopt this test. Although any test is somewhat arbitrary, the majority requirement has some rational basis underlying it.

In addition, this interpretation is favored by the precedent of a similar interpretation by the International Cooperation Administration of the identical language from the investment guaranty provisions of the Mutual Security Act of 1954.65 The only pertinent legislative history of the 1961 act also supports this position. Originally both the eligibility sections of the investment guaranty and investment survey titles as proposed by the Administration included as the key phrase on eligibility the requirement that "the majority beneficial interest is held by U.S. citizens." 66 This was ultimately changed in both places to "substantially beneficially owned by U.S. citizens." With regard to the change in section 233(a) relating to investment surveys, the report of the Conference Committee stated that the change was made by the Committee "in the belief that [the two phrases] were substantially identical."

and, this, too, was put into the statute. In addition; Congress limited each guaranty to \$10 million and all such guaranties to $\$ 90$ million.

64. FAA of 1961, § 221(b), 75 Stat. 429 (1961), 22 U.S.C. $\S 2181$ (b) (Supp. III, 1962). Curiously enough, the special authority of $\S 224$ for guaranties of investments of pilot demonstration housing projects in Latin America does not extend eligibility for such guaranties to wholly-owned foreign subsidiaries of U.S. corporations.

65. International Cooperation Adsinistration, Investarent Guaranty HandBook 5 (Rev. ed. 1960). [Hereinafter cited as HANDBO0K].

66. See $\S \S 221$ (b), 223 of S. 1983, introduced in the Senate on 1 fay 26, 1961, and $\S \S$ 221 (b), 233 of H.R. 7372, introduced in the House on the same day.

67. CONF. REP. at 53 (1961). 
of this statement is not wholly clear, it should probably be taken to mean that Congress preferred the form of statement adopted, but took the substance of the statement to be the requirement of majority beneficial interest by U.S. citizens. 68

The guaranty program authorized by the FAA of 1961 for eligible corporations is divided into three parts. The first part is the ICA (specific risk) guatrulty against losses arising from inconvertibility, expropriation, and war. Despite past failures, this is still the backbone of the program, receiving the largest ( $\$ 1.3$ billion) authorization. ${ }^{69}$ The second part is a guaranty against any risk (including business risk) except fraud or misconduct for which the investor is responsible, ${ }^{\mathbf{7 0}}$ a guaranty which was substituted for the previous DLF authority. AID has denominated these guaranties "all risk" guaranties. This was originally intended to be an experimental program and was to be reserved for high-priority projects. ${ }^{71}$ No project of sufficiently high priority apparently has presented itself, however, for no such guaranties have been isstied, although this authority has been in existence for a year. In spite of this unimpressive performance, Congress, in 1962, wisely increased the atthorization for this type of guaranty to $\$ 180$ million, double the amount authorized in the 1961 act. The third part, added in 1961, authorizes all risk guaranties for pilot housing projects in Latin America. ${ }^{72}$ This is a limited program ( $\$ 60$ million authorization) designed to stimulate investment only in such housing. While each of these sections is designed to stimulate foreign investment, they are essentially different programs with different problems and so will be discussed separately.

\section{Section 221(b)(1) Specified Risk Guaranties}

Section 221 (b) (1) of the FAA of 1961 authorizes the issuance of guarantics against the risk of inconvertibility, expropriation and war. ${ }^{73}$ The first, inconvertibility guaranties, are designed to protect American equity and loan investors in underdeveloped countries against the possibility that the host government will refuse to allow them to exchange local currency for U.S. dollars. Under these contracts AID agrees to exchange dollars for local currency where the local government has prohibited transfer or where the transfer can only be made at a rate less advantageous to the investor than the rate assured by the guaranty contract. It is important to note that the inconvertibility contract does not protect the investor against inconvertibility resulting from a law, regulation

68. It should be noted that where the stock of an applicant is wholly or partially owncd by another corporation, such ownership interest must, for purposes of determining eligibility, be attributed to the stockholders of the parent corporation in proportion to their ownlerslip interest in the parent, inasmuch as the statute clearly distinguishes between "U.S. citizens" and "corporations substantially beneficially owned" by such citizens, thus indicating that the term "citizen" is used in its ordinary reference to natural persons.

69. FAA of 1961, \& 221 (b) (1), 75 Stat. 429 (1961), 22 U.S.C. $\$ 2181$ (b) (1) (Supp. III, 1962).

70. FAA of 1961, § 221(b) (2), 75 Stat. 429 (1961), 22 U.S.C. $\$ 2181$ (b) (2) (Supp. III, 1962).

71. See 1961 Senate Hearings at 263-64. See note 19 supra.

72. FAA of 1961, § 224, 75 Stat. 432 (1961), 22 U.S.C. $\$ 2184$ (Supp. III, 1962).

73. FAA of 1961, 75 Stat. 429 (1961), 22 U.S.C. $\$ 2181$ (b) (Supp. III, 1962). 
or administrative determination in effect on the date of the contract. ${ }^{74}$ Protection extends, in the case of loan investments, to both principal and interest, and, in the case of equity investments, to twice the initial investment, except in special circumstances where more coverage is available. ${ }^{\text {it }}$

Expropriation guaranties are designed to protect U.S. investors against losses arising from actions of the host government which manifest expropriatory intent and which, in the case of an equity investment, destroy the value of the investment as a going concern, or which, in the case of a loan investment, prevent any payment of principal or interest for one year. ${ }^{76}$ Under these contracts AID agrees to buy the investor's interest if a covered risk occurs. Here, too, the coverage for equity investments includes the initial investment plus a limited amount of reinvested earnings, and coverage for loan investments includes both principal and interest. ${ }^{77}$ In the FAA of 1961, Congress made clear that breach of contract by the host government was intended to be included within the term "expropriation."78 This seemingly unimportant provision offers one of the best avenues for the investor to expand his coverage without increasing the fee.

74. The standard AID inconvertibility guaranty contract provides that AID will not be liable under the contract if

... the inability of the Investor to effect ... transfer ... result [s] from the operation of any law, decree, regulation or administrative determination which is recognized as being in effect by the governing authorities of the project country on the date of this contract and of which the Investor can reasonably be expected to have knowledge....

This provision is explained in HandBoor 13, as follows:

The convertibility guaranty contract in essence insures that a means, available at the time the contract is issued, for converting foreigrx currency investment receipts into dollars will continue for the life of the contract. Thus the ICA will not guaranty convertibility in the face of exchange regulations and practices under which it would be clear at the time a contract was issued that conversion could be efiected only through the guaranty.

The purpose of this provision is well accomplished when the foreign exchange law of the host country is clear. It is not clear what would happen when the law of the host country; in existence on the date the guaranty was issued, allowed the finance minister to suspend transfers whenever he felt that the foreign exchange position of the host country required it. If the finance minister prevented transfer pursuant to such a law, would the investor's ability to transfer have resulted from "the operation of [a] ... law, ... which is recognized as being in effect... on the date of the contract?" Probably it would not, but the answer is by no means certain. A better approach would be for AID to ascertain for itself before it issues the convertibility guaranty whether the investor will be allowed to repatriate funds.

75. HANDBOOK 15.

76. Id. at 17-18.

77. Id. at 18 .

78. Section 223(b) provides:

[T] he term "expropriation" includes but is not limited to any abrogation, repudiation, or impairment by a foreign government of its own contract with an investor, where such abrogation, repudiation, or impairment is not caused by the investor's own fault or misconduct, and materially adversely affects the continued operation of the project.

75 Stat. 431 (1961), 22 U.S.C. $\$ 2183$ (b) (Supp. III, 1962). This section merely gave legislative approval to a practice ICA had followed for some time. See, e.g., 1961 House Hearings at $949-50 ; 1961$ Senate Hearings at 905. 
Under this arrangement an investor may make an agreement with the host government relating to treatment of the investment. If this contract is breached by the host government and the effect of the breach is to prevent operation of the enterprise, ${ }^{79}$ the investor may collect under his expropriation guturanty. Theoretically, it would be possible for an ingenious investor to make an agreement covering taxes, labor, power, supplies, prices, transportation and all other foreseeable adverse actions which the government could take, thereby expanding his coverage well beyond the traditional limits of "expropriation."

The third specific risk guaranty is designed to protect American investors against loss resulting from war, revolution and insurrection. Under this contract, AID agrees to pay the investor the amount of any physical loss restiting from such events. ${ }^{80}$ Consequential damages, such as loss of profits, resulting from cessation of business activity, are not covered. ${ }^{81}$

\section{"All Risk" Guaranties}

In planning the new AID program in 1961, the foreign aid administrators noted that there were many possible risks not covered by the specific risk guaranties. ${ }^{82}$ These include all the regulatory and revenue producing measures which may appear reasonable to a young nationalistic government, but which make it exceedingly difficult for an investor to continue making profits. Other risks, such as riots and general strikes, which are virtually unknown in the United States, but which occur frequently in less developed countries, also are not covered.

Most, if not all, these risks could have been covered under the DLF anthority, ${ }^{83}$ but in the one equity guaranty issued by DLF ${ }^{84}$ three problems were encountered:

79. A crucial problem in any expropriation guaranty contract relates to the amount of injury which the investor must sustain before the action is considered expropriatory. The ICA contract states that in order to be considered expropriatory the action of the host government must for a period of one year prevent: (1) the foreign enterprise from excrcising substantial control over the use and disposition of its property; or (2) the investor from effectively exercising its right of participation in the control of the foreign enterprisc ; or (3) the investor from disposing of its capital stock in the foreign enterprise or any rights accruing therefrom. This would seem to include at least the case where the investor is prevented from operating his business. It is not clear whether lesser amounts of damage will be sufficient.

80. HANDBOOK 21. Revolution and insurrection have not been included but presumably will be treated the same as war risk.

81. HANDBOOK 21.

82. 1961 Senate Hearings at 906.

83. During the House hearings, Congressmam Judd made the following observation: This is the language in DLF legislation: "No guaranty on equity investment against normal business-type risk shall be made available by this subsection." By putting it thus negatively, we opened the door to almost everything else. I realize many never appreciated that the language provided such an open door. We couldn't get it over to them. It included guarantee against war risk, revolution; civil strife, and all the other things you have mentioned-all except business-type risks.

1961 House Hearings at 932 . Congressman Judd was as right about the law as he was wrong about the facts. See note 60 supra.

84. This guaranty covered the investment of Kaiser Aluminum and Chemical Corporil- 
(1) How should the covered risks be defined?

(2) How can the parties be certain that any particular damage was caused by a covered risk?

(3) How much injury must the investor suffer before the guaranty is triggered?

Because of these problems the foreign aid administrators proposed a new guaranty authority which they thought would be sufficiently broad to cover the holes in the specific risk guaranties, but which would avoid at least two of the three problems cited above.

In the new so-called "all risk" guaranty authority, the AID officials attempted to invert the variables of the guaranty equation. Thus, instead of insuring against 100 per cent of loss from certain specified political risks, AID proposed to insure against 75 per cent of loss from "all risks." 85 It would thus be unnecessary to define what risks were covered, and the investor would not have to establish a causal relationship between a covered risk and the injury.

Unfortunately, failure of the foreign aid agency and Congress to think through the ramifications of the "all risk" guaranty legislation carefully has resulted in a statute which does not solve or avoid any of the problems at which it was directed. First, it was intended that the "all risk" authority would allow AID to write a guaranty contract in which the covered risks did not have to be defined because "all risks" would be covered. This might have been the case had Congress not insisted that the contracts not cover "fraud or misconduct for which the investor is responsible." 80 Now, instead of defining what risks are covered, the contracting parties must define those risks which are not covered, i.e., fraud and misconduct. Second, it was thought that the "all risk" contract would avoid the likelihood of lawsuits to determine whether an injury resulted from a covered risk. Now, instead of proving that the loss arose from a covered risk, the investor must show that it did not arise from an excluded risk. The third, and most difficult problem, how much loss the investor must suffer before he can require AID to buy his investment, is also still with us unless AID agrees to buy the investor's interest at any time regardless of whether a loss has occurred.

In spite of the statute's shortcomings, the important question now is what form the so-called "all risk" guaranty contract should take. A number of possibilities are open to AID and the investor. First, AID could simply make a

tion and Reynolds Metal Company in the Volta Aluminum Company, Ltd., a Ghamian corporation (VALCO). Kaiser and Reynolds were insured against, inter alia, the risks of breach by the Government of Ghana of an agreement to arbitrate disputes; sanctions imposed by the United States or international organizations of which the United States is a member; and war, revolution, riot, political strikes, etc. Pursuant to this guaranty, the U.S. agreed to buy the interest of the investors if a specified dollar amount of loss (normally around $\$ 5$ million) resulted from any of these causes.

85. 1961 House Hearings at 906 . In the 1962 amendment AID was authorized to insure up to $100 \%$ of loan investments in housing projects. FAA of 1962, $\$ 104$ (a) (2), Pub. L. 87-565, 87th Cong., 2d Sess. (Aug. 1, 1962).

86. FAA of 1961, § 221 (b) (2), 75 Stat. 429 (1961), 22 U.S.C. $§ 2181$ (b) (2) (Supp. III, 1962). 
standing offer to buy 75 per cent of the investor's interest. Under this arrangement, AID would pay the investor 75 per cent of the original cost of his investment, plus retained earnings attributable to that portion, less any losses result. ing from fraud or misconduct of the investor. ${ }^{87}$ This is the maximum guaranty that AID could issue under its "all risk" authority. ${ }^{88}$ But, again, if past experience is any indication of what will be done in the future, there will probably be strong pressure from within AID to issue less than the maximum guaranty. Such "less-than-maximum" guaranties could take any number of forms. For example, AID could elect to cover only specified risks (presumably more than war, revolution, insurrection, inconvertibility and expropriation, but less than "all risk"). Under such an arrangement AID could agree to buy 75 per cent

87. Suppose, for example, that AID guarantees a $\$ 1,000,000$ loan from a U.S. investor to a foreign enterprise and that after $\$ 600,000$ has been repaid the foreign enterprise becomes insolvent and the investor decides to collect on his guaranty. The calculation of the amount he would collect could be as follows:

Original guarantied investment

Less: repayments

$\$ 1,000,000$ 600,000

Investor's interest outstanding

Percentage guarantied by AID

$\$ 400,000$

.75

Amount paid by AID to Investor

$\$ 300,000$

In such a case the investor would recover $\$ 900,000$ of his original $\$ 1,000,000$ investment. Of course, AID would also guaranty payment of interest, but this item has been omitted for the sake of clarity in the example.

In the case of equity investments the figures would be somewhat different, but the calculation would take a similar form. Suppose, for example, that a U.S. investor bought a $25 \%$ interest in a foreign enterprise for $\$ 1,000,000$, and that $50 \%$ of this investment was guarantied by AID under the "all risk" authority. Suppose also that during the first five years of operation $\$ 300,000$ of retained earnings attributable to the investor's interest are accumulated and losses of $\$ 100,000$ are realized as the result of fraud or misconduct for which the investor is responsible. In the following year the investor's interest is expropriated and he makes a claim under the guaranty. The amount he would collect would be calculated as follows:

Original guarantied investment

Retained earnings attributable to investor's interest

$\$ 1,000,000$ 300,000

Investor's total interest outstanding

Less: Losses from fraud \& misconduct

$\$ 1,300,000$ 100,000

Portion of investment to which guaranty is applicable $\$ 1,200,000$ Percentage guarantied by AID

Amount paid by AID to Investor

$\$ 600,000$

It should be noted that operating losses would not appear as a negative factor in this calculation because such losses occur as the result of business risks which are covered under the "all risk" contract. After the transaction has been completed AID and the investor will each own $12 \mathrm{r} / 2 \%$ of the stock of the expropriated enterprise or the equivalent in claims against the expropriating government.

88. Except, of course, for the $100 \%$ guaranty of housing loans. 
of the investor's interest for 75 per cent of what he paid for it, if a specified amount of loss was realized as a result of covered risks. ${ }^{80}$ Any number of other variations are also possible. Whether an investor receives a maximum guaranty or something less will probably depend upon whether he can convince AID that his investment is politically important and economically feasible.

Regardless of the type of guaranty the investor receives under section 221 (b) (2), it will be subject to a number of limitations which do not apply to specific risk guaranties and which did not apply to the predecessor DLF guaranties. First, the guaranteed project must "emphasize economic development projects furthering social progress and the development of small independent business enterprises." The only guide AID and potential investors have with respect to the meaning of this remarkable phrase is the following language in the Senate report:

It must emphasize economic development projects clearly related to social improvement in the country concerned. The committee, in approving this authority, expects that it will be used to encourage the development of small independent business enterprises, credit unions, cooperatives, lowcost housing projects and other similar activities. ${ }^{80}$

Although guaranties of other types of investments are not precluded so long as sufficient authority is reserved for the preferred categories, ${ }^{01}$ lack of clarity as to what other types fall within the statutory intent may cause AID to hesitate to use the authority outside the "credit union, cooperative and low-cost housing project" group.

Several other limitations which were not attached to the former DLF authority have also been imposed on the new "all risk" authority. For example, one loan guaranty under this section may exceed $\$ 25$ million, and other guaranties are limited to $\$ 10$ million. Since only 75 per cent of each investment may be covered (except for housing loans), however, loan investments up to $\$ 33 \mathrm{I} / 3$ million and other investments up to $\$ 13 \mathrm{I} / 3$ million may be insured. Also, for investments in excess of that amount there appears to be no legal reason why specific risk guaranties cannot be obtained on the excess. Thus, an arrangement conceivably could be made whereby the first $\$ 13$ million of a $\$ 50$ million equity investment could be covered by an "all risk" guaranty, and the last $\$ 37$ million covered by specific risk guaranties.

Not only is the amount of the guaranty limited, but so is the geographic area in which it may be issued. Pursuant to section 221(a) "all risk" guaranties may now be issued only in countries with which the President has agreed to institute the guaranty program. In the past this limitation had attached only to the ICA specific risk guaranty authority and was construed to require a de-

89. The most time consuming part of drafting the VAICO guaranty was the job of determining what constituted a loss: only physical loss? debts accrued but not paid? lost profits? Another vexing problem was the time period over which the losses could be accumulated.

90. S. REP. No. 612, 87th Cong., 1st Sess. 15 (1961).

91. Conf. Rep. at 52 (1961). 
tailed agreement with the host country for each type of guaranty. ${ }^{02}$ By June 1 , 1962, only 21 countries had signed agreements authorizing all three specific risk guaranties; $; 17$ others had signed expropriation and inconvertibility agreements; $; 4$ three had signed only convertibility agreements; $; 0$ and 38 had signed no agreements at all. ${ }^{96}$ If all three agreements are to be required for "all risk" guaranties, the possibilities for use of the authority in the near future will be substantially reduced.

The foreign aid officials who drafted the FAA of 1961 recognized the difficulties created by the agreement requirement. ${ }^{97}$ Accordingly, the new statute contains two provisions relating to such agreements. The first merely requires the President to obtain an agreement to institute the program before issuing guaranties for projects in any given country. ${ }^{98}$ The second provision requires the President to make suitable arrangements for the protection of American interests. ${ }^{99}$

92. See the draft note of the Investment Guaranties Staff, Agency for International Development, which may be used to institute the investment guaranty program (coveringt convertibility, expropriation and war risk guaranties) ; and Tidd, The Investment Gturanty Program and the Problem of Expropriation, 26 GEo. WASE. L. REv. 710 (1958).

93. Investment Guaranties Division, Internationaz Cooperation Administratron, Countries Where Investament Guaranties Are Availadle (1962). These are Afghanistan, China (Taiwan), Dominican Republic, Guinea, Israel, Ivory Coast, Jordan, Korea, Liberia, Morocco, Nepal, Nicaragua, Niger, Pakistan, Panama, Sierre Leone, Sudan, Thailand, Togo, Tunisia, and Viet-Nam.

94. These are Bolivia, Costa Rica, Ecuador, El Salvador, Ghana, Greece, Haiti, Honduras, India, Iran, Malaya, Paraguay, Philippines, Portugal, Spain, Turkey, and Yugoslavia.

95. Argentina, Chile, and Peru.

96. Baharian, Burma, Brazil, Cambodia, Cameroun, Central African Republic, Ceylon, Chad, Colombia, Congo (Leopoldville), Congo Republic (Brazzaville), Cyprus, Dahomey, Egypt, Ethiopia, Gabon, Guatemala, Indonesia, Iraq, Kuwait, Laos, Lebanon, Libya, Maligasy, Mali, Mauritania, Mexico, Muscat and Oman, Nigeria, Saudi Arabia, Senegal, Somali Republic, Syria, Togo, Truceal Sheikdoms and Quatar, Upper Volta, Venczuela, and Yemen.

97. The House Foreign Affairs Committee explained the problem as follows:

In past years these requirements have led to difficulties and delays in reaching agreements needed to begin the program. Many foreign governments require such agreements to be ratified by their legislatures. This sometimes occasions delays of many months and years even though there may be little doubt as to its eventual approval. Another major problem area is that many countries, because of constitutional or statutory provisions barring ownership of real property by a foreigin gove ernment, cannot commit themselves to recognize turnover of such property to the United States.

Honse Foreign Affairs Committee Report on H.R. 8400, H.R. Rep. No. 851, 87th Cong," 1st Sess. 36 (1961).

98. FAA of 1961, § 221(2), 75 Stat. 429 (1961), 22 U.S.C. $\S 2181$ (a) (Supp. III, 1962). See H.R. REP. No. 851, supra note 97 , at $32 ; 1961$ Senate Hearings at $264-65 ; 1961$ House Hearings at 948.

99. FAA of 1961, § 221 (d), 75 Stat. 429 (1961), 22 U.S.C. \$2181(d) (Supp. III, 1962). See 1961 House Hearings at 907-08, 921, 951-52; 1961 Senate Hearings at 264-65, 275, 282; H.R. REP. No. 851, supra note 97, at 36-37. 
AID officials took the position that the first requirement could be satisfied by any manifestation by the host country that it was willing to use the guaranty program to induce American investors to invest within its boundaries. ${ }^{100}$ Since the second provision requires the President to make "suitable arrangements" for protection of American interests but does not require that these arrangements take any, particular form, ${ }^{101}$ both provisions would be satisfied if a detailed agreement can be obtained. Where a detailed agreement cannot be obtained, other arrangements can be made to protect American interests. ${ }^{102}$ Such arrangements could take the form of a lesser agreement, a finding that there are reasonable prospects of obtaining such an agreement in the near future, or a finding that American interests will be adequately protected without an agreement. ${ }^{103}$

If past practices of the foreign aid agencies are followed, however, the flexibility allowed by the new statute may be negated in large part by the legislative history of the provision, ${ }^{104}$ since the agencies tend to rely heavily upon such history in evaluating courses of action. The Administration witness on guaranties, the Hon. Frank M. Coffin, may thus have preordained an inflexible approach when he stated that in all cases concerted efforts would be made to obtain agreements substantially similar to those obtained in the past. Perhaps this viewpoint rests upon a fear of opening the floodgates-that if a lesser agreement should ever be accepted from one country, it will be exceedingly

100. 1961 Senate Hearings at 279.

101. FAA of 1961, § 221(d), 75 Stat. 429 (1961), 22 U.S.C. $\$ 2181$ (d) (Supp. III, 1962). See 1961 Senate Hearings at 282; 1961 House Hearings at 951-52; H.R. REP. No. 851, supra note 97 , at 36-37.

102. The Administration's intentions in this regard were described as follows:

It is intended to continue to seek to conclude agreements which contain explicit recognition of the U.S. Government's right to subrogation and turnover of assets. However, this new provision will allow alternative arrangements suited to the particular circumstances of the case where legal obstacles in less-developed countries inhibit their entry into standard form bilateral agreements.

H.R. REP. No. 851, supra note 97, at 36-37.

103. See 1961 Senate Hearings at 264-65.

104. See, e.g., 1961 House Hearings at 264-65. It is important to note here the great concern AID and its predecessor agencies have had about their congressional relations and the peculiar effect this concern has upon the opinions of the General Counsel's office and, ultimately, upon the operations of the agency. The actions of AID will be challenged, if at all, not in a court but in congressional hearings. Accordingly, when an AID lawyer is asked for an opinion on the legality of a proposed action, he does not only ask himself how a court would decide the case but also, and more importantly, how Congress will react to it. The best guide to the reaction of Congress is the legislative history, and accordingly grcat weight is given to it. Of peculiar significance is the view agency officials talie of Administration testimony before Congress. Such testimony, no matter how ill prepared or speculative it might have been, may be regarded by the agency as a commitment to Congress. The effect such testimony has on future agency action will be determined by whether it is vague and general or specific and certain, and, also, by how important the agency regards the proposed action to be. This view of congressional testimony does not appear to be significantly. affected by how mistaken the witnesses may turn out to be or even whether Congress in any way relied upon the statements in question. 
difficult for the agency to obtain the standard agreement from any other country. Whatever the reason, AID very well may be reluctant to bargain seriously for anything but the standard agreement, thereby rendering its flexibility meaningless. ${ }^{105}$ In this connection, it may be significant that, as of this writing, the lack of such an agreement is preventing the issuance of guaranties in stuch important countries as Brazil, and, so far, no "increased flexibility" has been shown by AID.

An avenue that may be available to a potential investor planning a project in a country with which the United States has not executed an agreement is to attempt to persuade the host government to enter into an agreement with the United States containing all the standard provisions, but covering only his investment. ${ }^{106}$ Instead of having to follow the standard practices and procedures with respect to many unknown future projects, the host government might more readily agree to such practices and procedures only with respect to the particular investment before it.

\section{Housing Guaranties}

Section $224{ }^{107}$ authorizes the issuance of "all risk" guaranties up to a face amount of $\$ 60$ million for investments in "self-liquidating pilot housing projects" in Latin America. Since the coverage allowed under this section is basically the same as that allowed under section 221(b) (2), ${ }^{108}$ the "all risk" allthority (which authorizes guaranties of 100 per cent of loan investments in

105. See the discussion of this point in the Report on H.R. 11921 [The Forcign Assistance Act of 1962] of the House Committee on Foreign Affairs, H.R. REp. No. 1788, 87th Cong., 2d Sess. 8-11 (1962).

106. This approach was suggested in 1953 by the House Foreign Affairs Committee, but was never adopted by the agency. The Committee said:

Insistence by the executive branch on initiating the program in new countries through formal international agreements (not required by guaranty legislation) has been a stumbling block in some countries. It has been stated that the potentialitieg of the guaranty program can be defeated by this lack of flexibility, and that the best way to get started in the politically sensitive countries is with formal assurances applla cable to specific cases and not necessarily formalized international agreements. Assurances from foreign governments should be kept to a minimum, and used primarily to deter voluntary adverse actions by foreign governments.

Subcommttree on Foretgn Economic Poltcy of the House Foretgn Affatrs Commitree, Report on the Mutuat Securtty Act and Overseas Private Investanent $72-73$ (1953).

In addition to this approach, it may be possible to get AID to accept a higher than normal fee from the investor in lieu of an agreement with the host country. Section 221 (d) merely requires AID to make "suitable arrangements for protecting the interests of the United States Government." If the interests to be protected are merely the financial interests of the U.S. then a higher fee would seem to constitute "suitable arrangements." If on the other hand, AID construes the "interests" referred to in $\$ 221$ (d) as including not only financial interests but also the U.S. interest in persuading other countries to agrce to its views regarding the legal rights of foreign investments, then such an arrangement would not be "suitable."

107. 75 Stat. 432 (1961), 22 U.S.C. $\$ 2184$ (Supp. III, 1962), as amended by Pub. L. $87-565$, pt. 1, \& 104(c) (1962).

108. 75 Stat. 429 (1961), 22 U.S.C. $\$ 2181$ (b) (2) (Supp. III, 1962). 
housing projects), it has the same problems relating to coverage, c.g., the diffculty of proving that a given loss did not arise from an excluded risk, and the like. There is, however, one limitation on the issuance of all other guaranties-the bilateral agreement-which does not apply to section 224 guaranties. For some unknown reason, perhaps related to the fact that the housing guaranty section was not a part of the original bill, but was added as an amendment, ${ }^{109}$ the requirement that the President issue guaranties in countries "with the government of which the President has agreed to institute the program" and that he make "suitable arrangements" to protect the interests of the United States, does not apply to section $224 .{ }^{110}$

Conversely, however, there are a number of qualifications which have been imposed upon the housing guaranty section which were not imposed upon the others. Housing guaranties are available only in the "American Republics," but are not confined to the "less developed friendly countries and areas" in Latin America. Instead, such guaranties can be issued in any "rapidly developing" Latin American country. Does this mean that section 224 housing guaranties are not available in "less developed countries"? Are the terms "less developed" and "rapidly developing" mutually exclusive? The legislative history is devoid of any indication of congressional intention, and AID has not issued a formal interpretation. Probably, however, AID will determine that the terms are not mutually exclusive and will issue section 224 guaranties anywhere in Latin America. Realistically, it should not be otherwise. The difference in language probably was not intentional and should not be regarded as legally significant.

Second, section 224 guaranties are not available to cover the investments of wholly owned subsidiaries of American firms as section 221 guaranties are. Rather, section 224 guaranties are confined to

... investments made by United States citizens, or corporations, partnerships, or other associations created under the law of the United States or of any State or territory and substantially beneficially owned by United States citizens .....1111

Here, again, the reason for the difference between section 224 and section 221 is not to be found in the legislative history.

109. It was proposed by Senator George Smathers of Florida. 107 Coxc. Rec. 16015-17 (1961).

110. 75 Stat. 432 (1961), 22 U.S.C. $\$ 2184$ (Supp. III, 1962). In the FAA of 1961, both $\$ 221$ (a), 22 U.S.C. $\$ 2181$ (a), which imposes the country agreement requirement, and $\$ 221$ (d), 22 U.S.C. $\$ 2181$ (d), which imposes the suitable arrangements requirement, refer explicitly to guaranties under $\$ 221$ (b), 22 U.S.C. \$2181(b), without mention of $\$ 224,22$ U.S.C. $\$ 2184$; and $\$ 224$ itself includes no reference to the requirements of § 221 (a), 22 U.S.C. § 2181 (a), or § 221 (c), 22 U.S.C. § 2181(c). The argument is strengthened by the fact that $\$ 224$ (c), 22 U.S.C. $\$ 2184$ (c), does provide that the administrative provisions of $\$ \S 222$ (a) (b) (d) \& (e), 22 U.S.C. $\S \S 2182$ (a) (b) (d) \& (c), shall apply equally to $\S 224$ guaranties as they do to $\S 221$ (b) (2), 22 U.S.C. $\S 2181$ (b)(2) guaranties.

111. FAA of 1961, § 224(b), 75 Stat. 432 (1961), 22 U.S.C. $\S 2184$ (b) (Supp. III, 1962). 
Investments guarantied under section 224 must be in "self-liquidating private housing projects" of types similar to those insured by the Federal Housing Administration and suitable for conditions in Latin America. The legislative history does not indicate what a "self-liquidating private housing project" is, but this will probably be interpreted to mean those housing projects in which the homes are sold to the people living in them.

Finally, under section 224 the United States participates with the host country in guarantying private American capital. Does this mean that the United States and the host country must each guaranty a certain percentage of an investment? Probably it does not; rather, any form of host government participation in the project should suffice. Thus, the host government could supply the land or set up financing facilities. The idea of "participation" would seem to be satisfied so long as the host government, the United States, and the private investor cooperate in putting housing into the hands of the people.

\section{Conclusion}

It was noted in the introduction to this article that there is a significant role which private American foreign investment could play in the foreign aid program, but that so far it has not done so. In response to the potential investor's argument that sufficient inducement has not yet been offered, AID officials have frequently taken the position that the investment climate in the underdeveloped countries is so bad that no amount of inducement is likely to excite the interest of investors. In the extreme, this argument fails, since, with the proper legislation, it would be possible to guarantee circumstances, such as high aunual yield, under which even the most conservative investor could be induced to undertake investment. Thus, if the United States Government feels that private enterprise participation is sufficiently important, it can probably obtain far greater participation merely by increasing the inducements offered; the United States Government does have the potential means to obtain as much private enterprise participation as it wishes.

Since there is at present an obviously insufficient private enterprise participation in the program, the remedy appears to be to increase the inducements offered. Some expansion of private participation can be accomplished through the administrative actions suggested in this article. If a large increase in private participation is desired, however, Congress will have to provide more liberal inducement. In this connection the amounts authorized for "all risk" guaranties, "housing" guaranties, and investment surveys could be increased. In addition, the requirement of a bilateral agreement for investment guaranties could well be eliminated, and the vague and troublesome language of the "all risk" and "housing" guaranty legislation could be improved, or completely replaced, by much simpler language modeled after the old DLF authority.

No amount of legislative or administrative change is likely to produce results, however, unless the agency personnel can be induced to make use of the available tools; the overriding problem at the moment is this reluctance of AID and the State Department to use existing inducements for private investment. 
Moreover, this reluctance has produced an observable negative effect. For example, there appears to be some evidence that the so far unused AID "all risk" guaranty authority has in fact retarded, rather than increased, private American investment in underdeveloped areas. This rather curious result appears to have occurred because lenders who were beginning to consider the possibility of making commercial loans in underdeveloped areas have held back in order to see whether their proposed investments could be covered by an "all risk" guaranty. Of course, they dare not make the investment without such a guaranty if AID would give it, because AID would then conclude that for that type of investment it is not necessary, and therefore would not offer it in the future. It is not clear that this "wait and see" attitude has developed in cases other than that of the "all risk" guaranty, but this one experience should be sufficient to indicate that AID should either use its private enterprise authority or suggest its repeal.

If the private enterprise-foreign aid program cannot go forward with the support, or at least the acquiescence, of AID and State Department personnel, it might be well to examine and try to meet their objections to the use of private American investment. It was noted in the introduction to this article that at times these officials have objected to private investment by American firms in underdeveloped countries because there appeared to be some doubt whether such investment would further the foreign policy interests of the United States. It is clear, however, that many American firms have succeeded in making their operations acceptable to foreign governments, by insuring that their citizens share the benefits of economic development.

The methods used by American firms to distribute the benefits of development to the local citizens vary with the country and with the investor. In general, however, two principal approaches seem to be emerging. The first approach, exemplified by Kaiser Industries in Argentina, Brazil and India, is to ensure that a large proportion of its stock (priced in very small denominations) is bought by local middle class investors. ${ }^{112}$ Thus, the local as well as American investors profit from the growth of the enterprise and it becomes the interest of local investors to see that American enterprise is not unduly hampered by actions of the host government. The second approach, used by Firestone Rubber Company in Liberia and by Creole Petroleum Company in Venezuela, is to provide communities with services previously unavailable to them. For example, Creole Petroleum operates many schools, hospitals and stores on a non-profit basis, in addition to supplying housing and recreational facilities for its employees. As the community develops, control of these facilities is transferred to local private or public groups, while Creole continues to supply financial support. ${ }^{113}$ The result is not only to create some measure of community dependence

112. Opportunity Unlimitcd, address by Henry J. Kaiser, Jr., Executive Club of ChiCago, April 29, 1960.

113. Taylor \& Lindenan, United States Business Perforacance Angond 38-57 (1955). (This is the fourth case study in a National Planning Association series on United States business abroad.) 
on the company, but also to generate a considerable reservoir of good will. Which of these approaches works best depends upon the country involved, but both approaches have had the effect of distributing the benefits of economic development throughout a large segment of the economy, and thits of creating broadly based support for the private investor.

In areas where nationalistic feelings are running very high, much of the potential criticism of foreign private investment can be met in advance by a joint ownership arrangement, in which the American firm takes a minority position, if the eligibility sections can be interpreted to permit this. ${ }^{114}$ Such a company is less likely to be considered a "foreign firm" by the local citizens because majority control is in the hands of their own nationals. Accordingly, there is much less likelihood of harassment or expropriation by the local government, while the American firm's knowledge and experience can still be brought to bear on the problems.

Since these measures go far toward insuring that private American investment abroad also serves the foreign policy interests of the United States, it would seem that a method should be found for imposing such obligations on all American investors who operate abroad with the financial assistance of the United States Government. In fact, it is possible to make such obligations part of the contract between the United States and the American investors, pursuant to which AID makes financing available. AID has begun to recognize the benefits of such a program, and has alreacly required some investors to support local clinics and contribute to social development funds in return for AID assistance to their project. In one case an American investor, whose enterprise was to be established in a politically sensitive area, was required to set up an elaborate selection and training program on a Peace Corps model for those of its employees who would be sent to the host country. Personality factors as well as technical abilities were to be considered in making the selection. Persons who might find it difficult to adapt to relatively primitive surroundings were to be weeded out. Those selected were to be given intensive short term training by specialists in local customs. Where necessary, longer term language courses were to be given.

Continuing to impose such obligations on AID assisted investors on a broader basis should go far toward removing the legitimate objections of State Department and AID personnel-as well as those of the foreign governments themselves-to the use of private American investment in the foreign aid program. But there is a possibility that other objections, stemming from a bureaticratic preference for government-to-government operations will remain. Stch objections can, of course, be overcome by determined administrative action. But if such action is not forthcoming, it may be necessary for Congress-if it wishes more private participation-to enact legislation requiring a specified amount of all foreign aid funds to be used for private projects.

114. See text accompanying notes 64-68 supra. 


\title{
THE YALE LAW JOURNAL
}

ARMAAND DeRfNer
JOHN HART Ely
JOEL JAY FINER
ROBERT M. SHEPARd
Note \& Comment
Editors

Barbara A. BABcock

RoBERT A. BURT

EDWARd R. CoHen

Robert E. COOPER

Theodore B. Donson

AsHLEY L. Ford

JoSEPH W. GELB
Sangwoo AmN

Managing Editor

LEE A. ALBERT

Editor-in-Chief

AILEN I. IsaAcson

ALAN D. JACOBSON

ANTHONY S. KoLKER

Miartin Levine

JOHN J. MCATEE, JR.

ARThur A. MIUNISTERI

JaMres J. MIURRAY

\author{
Edgar S. Carn \\ BRUCE E. FrITCE \\ Article \& Bools \\ Review Editors
}

ALAN R. NOVAK

Topics Edilor

\author{
Robert E. Phay \\ Rosert B. Sczherder \\ Peter L. Strauss \\ ROGER W. TO2SPRT: \\ Steven ML. Uarns \\ Euriotr J. Warss \\ WARREN G. WiCKERSHANS
}

\section{MAARIE MCMIAEON \\ Basiness Secretary}

\section{CONTRIBUTORS TO THIS ISSUE}

Clyde W. Sumarers. B.S. 1939, J.D. 1942, University of Illinois; LL.Ar. 1946, J.S.D. 1952, Columbia University.

JAN G. Deutsch. B.A. 1955, Yale University; B.A. 1957, Clare College, Cambridge; LL.B. 1962, Ph.D. 1962, Yale University.

BRUCE E. ClubB. B.B.A. 1955, LL.B. 1958, University of Afinnesota.

VerNe W. VANCE, JR. B.A. 1954, LL.B. 1957, Harvard University.

JosePF A. PAGE. B.A. 1955, LL.B. 1958, Harvard University.

Joseph W. Bishop, JR. B.A. 1936, Dartmouth College; LL.B. 1940, Harvard University.

Gerald A. BerLrN. B.A. 1940, University of Virginia; LL.B. 1947, Yale University.

RaLPH S. Brown, JR. B.A. 1935, LL.B. 1939, Yale University. 